\title{
一原 著一
}

\section{マウス皮虐移植における抗 $\alpha \beta-\mathrm{T}$ 細胞 リセプター抗体の効果}

\author{
内山 喜一郎 \\ 日本医科大学外科学第 2 教室
}

Effect of anti- $\alpha \beta$ T cell receptor monoclonal antibody on skin allograft rejection in mice

\section{Kiichiro Uchiyama}

The Second Department of Surgery, Nippon Medical School

$T$ cell receptors recognize foreign antigens in the context of glycoproteins encoded by the major histocompatibility complex (MHC). $\alpha \beta$ T cell receptor ( $\alpha \beta$ TCR) consists of disulfide-linked heterodimeric glycoproteins composed of $\alpha$ - and $\beta$-chain. H57-597 is a hamster monoclonal antibody which is directed against the $\beta$ chain of the murine TCR complex. We purified an anti- $\alpha \beta$ TCR monoclonal antibody (anti-V $\beta \mathrm{mAb}$ ) which had very similar properties to $\mathrm{H} 57-597$, and examined the effect of this $\mathrm{mAb}$ in complete H-2-disparate skin allograft. $\mathrm{C} 57 \mathrm{BL} / 6$ (B6) mice grafted with DBA abdominal skin were injected intraperitoneally with $250 \mu \mathrm{g}$ of anti-V $\beta$ mAb just after grafting. These B6 mice rejected their skin grafts with a mean survival time (MST: $8.5 \pm 0.8$ days) similar to that of the control mice (MST: $8.5 \pm 0.5$ days). To examine the modulation of TCR and the T cell function, $\mathrm{B} 6$ mice were injected with only one dose of $250 \mu \mathrm{g}$ of anti-V $\beta \mathrm{mAb}$, and lymphocytes from peripheral blood (PBL), lymph nodes and spleen were tested by flow cytometric analysis (FCM), mixed lymphocyte reaction (MLR) and cell mediated lympholysis (CML) on days $3,7,14,28,42$, and 56 post-injection. There were no detectable Thy $1.2^{+} \alpha \beta \mathrm{TCR}^{+}$cells present in these organs by FCM for the first 1 week after the administration of $\mathrm{mAb}$, but about $26 \%$ of Thy-1. $2^{+}$cells stil remained. The numbers of Thy $-1.2^{+} \alpha \beta \mathrm{TCR}^{+}$cells had recovered fully in PBL, but only up to $60 \%$ of control levels in the lymph nodes and spleen by day 56 post-treatment. Spleen cells from B6 mice treated with $250 \mu \mathrm{g}$ of anti- $\mathrm{V} \beta \mathrm{mAb}$ demonstrated significant suppression of both donor-specific proliferative response in MLR and cytotoxicity in CML up to 28 days post-injection. Then the response fully recovered by day 56 post-injection. These data indicate that anti- $\mathrm{V} \beta \mathrm{mAb}$ treatment in mice leads to the rapid and nearly total depletion of $\alpha \beta \mathrm{TCR}^{+}$cells. In order to deplete more $\alpha \beta \mathrm{TCR}^{+}$cells and acquire longer graft survival, $100 \mu \mathrm{g}$ or $250 \mu \mathrm{g}$ of mAb was injected on days $3,7,10$, following the injection just after skin grafting. These B6 mice retained their grafts with MST of $12.2 \pm 1.5$ or $12.8 \pm 0.8$ days, respectively. B6 mice administered with $250 \mu \mathrm{g}$ of mAb every day after grafting also retained grafts with similar MST of $10.3 \pm 0.8$ days, but survival time was prolonged for no longer than 12 days. Despite the depletion of all $\alpha \beta \mathrm{TCR}^{+}$cells from peripheral blood, lymph nodes and spleen with anti-V $\beta \mathrm{mAb}$, Thy $-1.2^{+} \alpha \beta$ TCR cells still remained, and these cells were thought to include $\gamma \delta \mathrm{TCR}^{+}$cells capable of antigen-specific immunological responses. The data suggested that administration of anti- $\mathrm{V} \beta$ mAb alone was not enough to make skin allografts survive longer than 12

Correspondence to Kiichiro Uchiyama, The Second Department of Surgery, Nippon Medical School First Hospital, 3-5-5, lidabashi, Chiyoda-ku, Tokyo 102, Japan 
days, and certain Thy $-1.2^{+} \alpha \beta$ TCR cells and other unknown factors might play an important role in the response to diverse foreign antigens in epithelia.

Key words: T cell receptor, monoclonal antibody, H57-597, skin allograft, rejection

\section{緒 言}

臓器移植後における移植片拒絶反心は， T 細胞 が主役の反応である。移植抗原を認識したへル パーT 細胞は様々なリンホカインを産生し放出 する. 放出されたりンホカインによって活性化し た各種エフェクター細胞は，移植組織を傷害し移 植片を拒絶する，T細胞はその抗原特異的リセプ ター (T cell receptor, TCR) を介して, 抗原分 子と抗原提示細胞 (antigen presenting cell, APC) 表層上の主要組織適合抗原 (major histocompatibility complex, MHC) との複合体を認 識することが知られている ${ }^{1 \sim 3}$. 移植組織の生着を 延長するために，現在様々な免疫抑制剂（副腎皮 質ホルモン, サイクロスポリン A, FK506, 抗リ ンパ球抗体，抗接着分子抗体，など）を組み合わ せた免疫抑制療法が行われている 抗 CD3抗体 (OKT3) ${ }^{6)}$, 抗 IL-2リセプター抗体 ${ }^{7}$, 抗 ICAM-1/抗 LFA-1抗体 ${ }^{8)}$ などは, 移植免疫を担 うリンパ細胞の活性を直接抑制する抗体として成 果が注目されているが，その結果には未だ問題が 残されている.

T 細胞の抗原譛識に主要な役割を果たす TCR 分子は, $90 \%$ 以上が $\alpha$ 鎖と $\beta$ 鎖が S-S 結合した $\alpha \beta \mathrm{TCR}$ であり ${ }^{9 \sim 11)}$, 残りは $\gamma$ 鎖と $\delta$ 鎖が結合し た $\gamma \delta \mathrm{TCR}^{12,13)}$ 加なっている. TCR と機能単位 をなす CD3分子群は, $\gamma, \delta, \varepsilon, \xi, \eta$ の 5 つサ ブュニットから成り ${ }^{14)}$, TCR を介する抗原刺激を 細胞内に伝達する役割を担っている，H57-597(以 下 H57と略す） は $\alpha \beta$ T 細胞の $\beta$ 鎖を認識するモ ノクローナル抗体であるが, in vitro で, すべての $\alpha \beta \mathrm{TCR}^{+}$細胞に結合し $\gamma \delta \mathrm{TCR}^{+}$細胞には反応し ないこと, ウェルの底面に接着固定した抗体には $\alpha \beta \mathrm{TCR}+$ 細胞を活性化し IL-2を産生させる働き のあることが報告されている15).

本論文は, H57に類似した抗 $\alpha \beta$ TCR モノク ローナル抗体（以下抗 $\mathrm{V} \beta \mathrm{mAb}$ と略す）を作成
し，この抗体をマウスに投与することによって $\alpha \beta \mathrm{TCR}^{+} \mathrm{T}$ 細胞の機能を抑制し, 同種皮膚移植片 の拒絶に $\alpha \beta \mathrm{TCR}^{+} \mathrm{T}$ 細胞以外の細胞が関与する か否かを検討したものである. 抗 $\mathrm{V} \beta \mathrm{mAb}$ 投与 による末梢血, リンパ節, 脾臓中の $\alpha \beta \mathrm{TCR}^{+} \mathrm{T}$ 細 胞の数と割合, 機能などの変動を Flow cytometry (FCM), 混合リンパ球反応 (Mixed lymphocyte reaction, MLR), 細胞媒介性リンパ 球溶解反応 (Cell mediated lympholysis, CML) で測定し，移植片の拒絶に及济す $\alpha \beta \mathrm{TCR}^{+} \mathrm{T}$ 細 胞と $\gamma \delta \mathrm{TCR}^{+} \mathrm{T}$ 細胞の役割について考察を加え た.

\section{研究材料および方法}

1) 動物: $\mathrm{C} 57 \mathrm{BL} / 6\left(\mathrm{~B} 6, \mathrm{H}-2^{\mathrm{b}}\right), \mathrm{DBA} / 2(\mathrm{DBA}$, H-2 ${ }^{\mathrm{d}}$ ) は Jackson Laboratory（USA）により購 入した. C.B-17/Icr scid (sicd,H-2 ${ }^{\mathrm{d}}$ ) は, Emil R. Unanue 博士 (Washington University, St. Louis, MO, USA)より供与された。実験には，すべて生

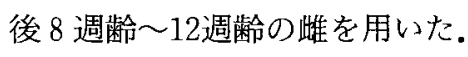

2) Media：細胞培養および MLRやCMLの 測定には, Dulbecco's Modified Eagle Medium (GIBCO Laboratories, USA) $に 1.0 \mathrm{mM}$ sodium pyruvate, $1 \times 10^{5} \mathrm{U} / \mathrm{L}$ penicillin, $1 \times 10^{5} \mu \mathrm{g} / \mathrm{L}$ streptomycin, $116 \mathrm{mg} / \mathrm{L}$ L-arginine, $36 \mathrm{mg} / \mathrm{L}$ L-asparagine, $2 \mathrm{~g} / \mathrm{L} \quad \mathrm{NaHCO}_{3}, 1.5 \mathrm{mM} \quad \mathrm{L}$. glutamine, $10 \mathrm{mM}$ HEPES buffer および $5 \times 10^{-5}$ M 2-mercaptoethanol を加えたものを使用した. FCM, MLR, CML には $5 \sim 10 \%$ 割合に fetal bovine serum (Hazleton Biologics, USA) を加 えた培養液を用いた。

3）モノクローナル抗体：Kubo らの方法 ${ }^{15)}$ に 準じて抗 $\alpha \beta$ TCR 抗体（抗 V $\beta$ mAb）を作成し た. 要約すると, マウス $\mathrm{T}$ 細胞ハイブリドーマ DO-11. 100 TCR を分離して得た TCR rich 分画 で免疫したハムスターの脾臟から B 細胞を分離 し, マウス骨髄腫細胞 P3X63AG8.653と細胞融合 
させ $\mathrm{V} \beta$ 鎖特異的ハイブリドーマを作成した。こ のハイブリドーマを scid マウスの腹腔内に注入 することで貯留する腹水から抗体を精製した。こ の抗体が B 細胞と反応しないことは FCM で確 認している (data未発表).

4）皮膚移植：Billingham \& Medawar らの方 法 $^{16)}$ 用いて DBA マウスの腹壁皮膚をそれぞれ B6マウスの背側に移植した. 皮膚移植後に抗 V $\beta$

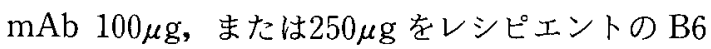
マウス腹腔内に投与した。投与方法により, 術直 後 1 回のみ, 術直後と術後 $3,7,10$ 日目, 術直 後から毎日投与の各群に分けた。術後 7 日目に移 植片をおおっていたガーゼを除去し，以後毎日， 移植皮膚片が拒絶されるまで観察した。移植皮膚 片の90\%以上の領域が壊死になった日を拒絶日と 定めた。なお，対照群には抗 $\mathrm{V} \beta \mathrm{mAb}$ の代わりに 八ムスターIgG (Cappel 社, USA) 250 $\mu$ g を投与 した。

5) Flow cytometry (FCM) : 抗 $\mathrm{V} \beta$ mAb 250 $\mu \mathrm{g}$ を $\beta 6$ マウスの腹腔内に 1 回注射し, $3,7,14$, 28，42抢よび56日目にそれぞれ $2 \sim 3$ 匹のマウス を末梢血採血後屠殺し, 脾藏, リンパ節（腋窩， そけい部, 腸間膜）を摘出し，リンパ球を分離し た.末梢血リンパ球 (Peripheral blood lymphocyte, PBL) は Ficoll-Hypaque 比重遠心 法で分離精製した。脾細胞浮遊液は, single cell suspension を作成後比重遠心法で分離調整した。 リンパ節は Ficoll-Hypaque を用いることなく single cell suspension を作成した. 対照群の細胞 浮遊液は $2 \sim 3$ 匹の無処置 B6マウスから同様に リンパ球を採取調整した。これら 3 種のリンパ球 を, Biotin を conjugateした抗 V $\beta$ mAb あるい は抗 Thy-1.2 mAb (Becton Dickinson 社, USA), streptavidin-coupled phycoerythrin, FITC-conjugated goat anti-rat IgG (Caltag Laboratories, USA) を用いて単染色及び二重染 色 L, FACScan flow cytometer (BectonDickinson Immnocytometry Systems 社, USA) で分析した.

6) MLR : 抗 V $\beta$ mAb $250 \mu \mathrm{g}$ を無処置の B6マ ウス腹腔内に注射後， $3 ， 7 ， 14 ， 28 ， 42 ， 56$ 日
目にそれぞれ 2 〜 3 匹のB6マウスを屠殺し,摘出 した脾臓から $5 \times 10^{6} / \mathrm{ml}$ の脾細胞浮遊液を作り反 応細胞とした。刺激細胞は DBA マウスの脾細胞 浮遊液 $5 \times 10^{6} / \mathrm{m} l$ に20GyX 線照射し使用した. 96 穴マイクロプレートの各ウェル内にそれぞれ 100 $\mu l$ の反応細胞と刺激細胞を混合し, $37^{\circ} \mathrm{C}, 5 \% \mathrm{CO}_{2}$ の条件下で $2 \sim 5$ 日間培養した。なお，対照には 刺激細胞として DBA の代方りに20Gy を照射し た B6マウスの脾細胞を使用した。培養 $2 \sim 5$ 日 後, 各ウェルに $1 \mu \mathrm{Ci} の^{3} \mathrm{H}$-サイミジンを加え,さら に24時間培責した。反応細胞のサイミジンの取り 込みはセルハーベスターを用いて濾紙上に吸着さ せ細胞を乾燥, 液体シンチレーションカウンター で各ウェルの cpm を測定した。結果は，抗 V $\beta$ $\mathrm{mAb}$ 投与 (treated) B6の MLRと非投与 (untreated) B6の MLRについて，それぞれの刺 激時 (allogeneic MLR) と非刺激時 (syngeneic MLR）の差をとり $\Delta \mathrm{cpm}$ として表した。

$\Delta \mathrm{cpm}=$ allogeneic MLR

- syngeneic MLR

7) $\mathrm{CML}$ : MLR の実験で, 抗 $\mathrm{V} \beta \mathrm{mAb} 250 \mu \mathrm{g}$ を腹腔内に注入した B6マウスから CML の反応 細胞 (B6 splenocyte $5 \times 10^{6} / \mathrm{m} l$ ) を調整し, DBA マウスより刺激細胞 (irradiated DBA splenocyte $\left.5 \times 10^{6} / \mathrm{m} l\right)$ を調整した。 反応細胞 $17 \times 10^{6}$ 個 (3.4 $\mathrm{m} l)$ とX 線照射した刺激細胞 $22 \times 10^{6}$ 個 $(4.4 \mathrm{~m} l)$ を $37^{\circ} \mathrm{C}, 5 \% \mathrm{CO}_{2}$ 条件下で 5 日間混合培養して感 作，細胞を回収しエフェクター細胞とした．標的 細胞は ${ }^{51} \mathrm{Cr}$ で標識したマウス骨䯣腫細胞 P815 (H-2d $)$ と EL-4 (H-2 $\left.2^{\mathrm{b}}\right)$ を $2 \times 10^{3}$ 細胞/ウェ ルの割合で用いた. エフェクター細胞と標的細胞 の比 $(\mathrm{E} / \mathrm{T})$ は $3: 1,10: 1,30: 1,100: 1$ とし，96穴マイクロプレートを用いて総量 $200 \mu l$ となるよう混合， $37^{\circ} \mathrm{C} ， 5 \% \mathrm{CO}_{2}$ 下 4 時間培養し た. 反応後の上清 $100 \mu 1$ を各ウェルより採取し, 放 出された ${ }^{51} \mathrm{Cr}$ をガンマカウンターで測定した。抗 $\mathrm{V} \beta \mathrm{mAb}$ 非投与 (untreated) B6マウスを用いて 同様のCMLを行い対照とした。結果は,\% specific lysis として下記の式で計算した。

$\%$ Specific lysis= 
$\frac{\text { experimental } \mathrm{cpm} \text {-spontaneous } \mathrm{cpm}}{\text { total } \mathrm{cpm}-\text { spontaneous } \mathrm{cpm}} \times 100$

8）統計処理：皮着移植を受けた各群間の統計 学的検定には Tukey's studentized range test を 用いた. $\mathrm{p}<0.05$ もって有意差とした.

\section{結 果}

\section{1. 移植皮虚生着期間}

対照としてハムスターIgGを投与したアロ皮膚 移植群 (group 1，2) は投与回数に関係なく $8.0 \pm$

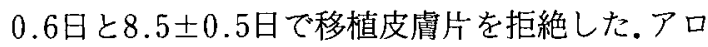
皮膚移植十抗 $\mathrm{V} \beta \mathrm{mAb}$ 投与群では, 抗 $\mathrm{V} \beta \mathrm{mAb}$ 投与量 $100 \mu \mathrm{g}$ でも $250 \mu \mathrm{g}$ でも, 術当日 1 回限りの

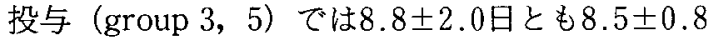
日で拒絶されたが，術直後，3，7，10日目に投

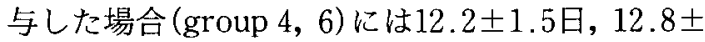
0.8 日と生着期間が約 4 日間延長した（p< 0.001). $250 \mu \mathrm{g}$ を術後毎日投与した群（group 7) も生着期間が10.3土0.8日と延長する（ $\mathrm{p}<$ 0.001).しかし, group 4, group 6に比べ生着期 間が延長することはなかった。抗 $\mathrm{V} \beta \mathrm{mAb}$ 投与 によると思われる副作用は特に認められなかった (Table 1).

\section{2. $\alpha \beta \mathrm{TCR}^{+}$細胞数と割合の変化}

抗 $\mathrm{V} \beta \mathrm{mAb}$ 抗投与したマウスのリンパ節, 脾

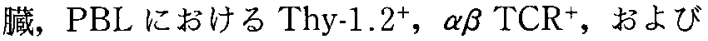
Thy $-1.2^{+} \alpha \beta$ TCR + の各 $\mathrm{T}$ 細胞数の割合の変動を 対照の無処置 B6マウスのそれと比較し\% Control として表した (Fig. 1). Thy-1.2 ${ }^{+} \alpha \beta$ TCR $^{+}$ 細胞は, 抗 $\mathrm{V} \beta \mathrm{mAb}$ 投与 3 日後にはいずれもほ ぼ $0 \%$ となった。この状態が 7 日目まで続き，14 日目から回復し始め，56日目にはリンパ節，脾で は対照の58.0, 59.3\%, PBL では $129.7 \%$ だ回復 した。一方, Thy-1.2+細胞は3 日目には 17.7〜36.6\%（平均26.1\%）まで低下し，14日目 から急激に回復が始まった。56日目には，リンパ 節, 脾で75.0,78.3\%, PBL で119.1\%に回復した。 リンパ節における Thy-1.2+ $\alpha \beta$ TCR ${ }^{+}$細胞の回復 過程を FCM で解析した (contour plot) のが Fig. 2 である。 3 日目には Thy-1.2 $\alpha \beta$ TCR ${ }^{+}$細胞が ほほ０％にまで減少するが，7日目には Thy-1.2+ $\alpha \beta$ TCR-細胞が出現した. 14日目には Thy-1.2+ $\alpha \beta$ TCR ${ }^{-}$が出現した。 14日目から Thy-1.2+ $\alpha \beta$ $\mathrm{TCR}^{-}$細胞が減少し Thy-1.2 ${ }^{+} \alpha \beta$ TCR T $^{+}$細胞が出 現し始め，56日目には Control のパネルと比較し て，かなり正常に近い状態にまで回復しているの が確認できた。

Table 1 Treatment with anti-V $\beta$ mAb and skin allograft survival

\begin{tabular}{|c|c|c|c|c|c|c|c|}
\hline Group & Donor & Treatment ${ }^{\mathrm{a}}$ & Dose & $\mathrm{n}$ & $\begin{array}{c}\text { Graft survival } \\
\text { (days) }\end{array}$ & $\begin{array}{c}\text { MST } \pm \text { SD }^{b} \\
\text { (days) }\end{array}$ & $\mathrm{P}^{\mathrm{c}}$ \\
\hline 1. & DBA & Hamster IgG & $250 \mu \mathrm{g}$ Day $0,3,7,10$ & 6 & $7,8,8,8,8,9$ & $8.0 \pm 0.6$ & \\
\hline 2. & DBA & Hamster IgG & $250 \mu \mathrm{g}$ Every day & 6 & $8,8,8,9,9,9$ & $8.5 \pm 0.5$ & \\
\hline 3. & DBA & anti- $\mathrm{V} \beta \mathrm{mAb}$ & $100 \mu \mathrm{g}$ Day 0 only & 6 & $7,7,7,10,11,11$ & $8.8 \pm 2.0$ & $\mathrm{NS}^{d}$ \\
\hline 4. & DBA & anti.V $\beta \mathrm{mAb}$ & $100 \mu \mathrm{g}$ Day $0,3,7,10$ & 6 & $10,11,12,13,13,14$ & $12.2 \pm 1.5$ & $<0.001^{\mathrm{e}}$ \\
\hline 5. & DBA & anti- $\mathrm{V} \beta \mathrm{mAb}$ & $250 \mu \mathrm{g}$ Day 0 only & 6 & $7,8,9,9,9,9$ & $8.5 \pm 0.8$ & $\mathrm{NS}^{t}$ \\
\hline 6. & DBA & anti-V $\beta \mathrm{mAb}$ & $250 \mu \mathrm{g}$ Day $0,3,7,10$ & 6 & $12,12,13,13,13,14$ & $12.8 \pm 0.8$ & $<0.001^{8}$ \\
\hline 7. & DBA & anti. $\mathrm{V} \beta \mathrm{mAb}$ & $250 \mu \mathrm{g}$ Every day & 6 & $9,10,10,11,11,11$ & $10.3 \pm 0.8$ & $<0.001^{\mathrm{h}}$ \\
\hline
\end{tabular}

C $57 \mathrm{BL} / 6$ female mice were grafted with female DBA abdominal skin on the posterior-lateral thorax, and injected with either anti-V $\beta$ mAb or Hamster $\operatorname{IgG}$ intraperitoneally at each time point. The grafts were inspected daily until rejection (defined as $>90 \%$ necrosis of the graft).

Intraperitoneal injection

'MST : mean survival time, SD : standard deviation

'Tukey's studentized range test

d, $P$ values : $p=N S$ for comparisons of group 1 vs. 3,5

e.g.hP values : $p<0.001$ for comparisons of group 1 vs. 4,6 ; and for group 2 vs. 7 


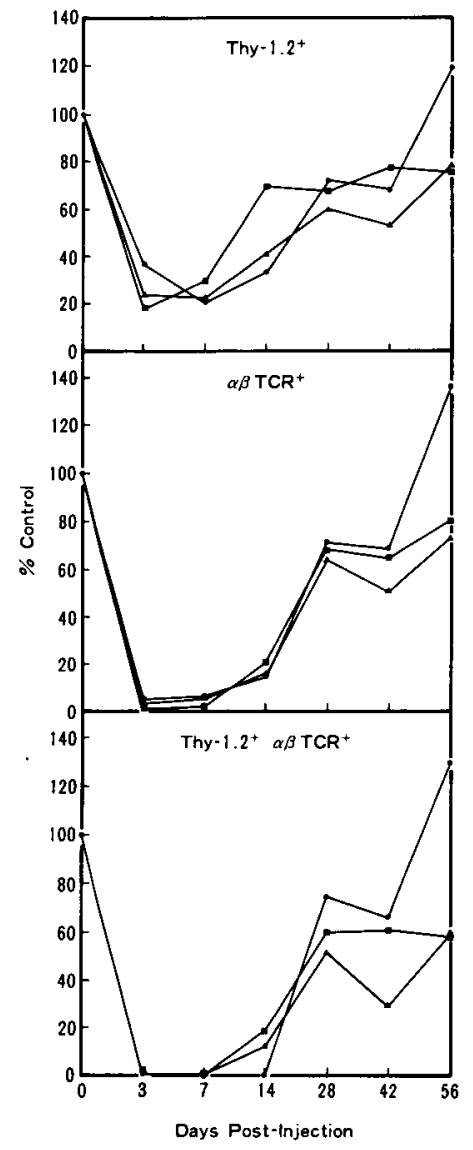

Fig. 1 Effect of anti-V $\beta$ mAb on $\mathrm{T}$ cell subsets. After single dose $(250 \mu \mathrm{g})$ of anti- $\mathrm{V} \beta \mathrm{mAb}$ injection, lymphocytes from spleens $(\mathbf{\Lambda})$, lymph nodes $(\boldsymbol{\square})$, and peripheral bood (a) from two or three mice were pooled respectively, and examined by single(Thy-1.2+ or $\alpha \beta \mathrm{TCR}^{+}$) and two-color (Thy-1.2 $2^{+} \quad \alpha \beta$ TCR $\mathrm{TCR}^{+}$) flow cytometry. Staining was done with biotinylated anti$\mathrm{V} \beta \mathrm{mAb}$ and streptavidin-coupled phycoerythrin for TCR $\alpha \beta^{+}$cells: antiThy-1.2 mAb and FITC conjugated goat anti-rat IgG for Thy-1.2+ cells. Thy-1.2 $2^{+}$ TCR $\alpha \beta^{+}$, and Thy $-1.2^{+}$TCR $\alpha \beta^{+}$cells are plotted as percent control.

\section{MLR の変動}

抗 $\mathrm{V} \beta \mathrm{mAb}$ を腹腔内投与した $\mathrm{B} 6$ マウスの脾 臓を, 抗体投与後種々の日に摘出, その脾細胞を X線照射した DBA 脾細胞と共に培養し脾細胞の 増殖反応を観察した(Fig. 3).2 日から5日まで
の混合培養で最大の取り込みを示すのは培養 4 日 から 5 日であった。 5 日間混合培養した脾細胞の 増殖反応 (anti-V $\beta \mathrm{mAb}$-treated $\Delta \mathrm{cpm} /$ untreated $\Delta \mathrm{cpm} \times 100)$ は，抗 $\mathrm{V} \beta \mathrm{mAb}$ 投与により 3 日目に は対照の $2.6 \%$ ま低下，7，14，28日目でもそれ ぞれ19.3\%，25.5\%，12.0\%と抑制されていた。 その後 42 日目には，77.6\%と急激に回復し始め， 56日目には完全に（126.1\%）回復した。

\section{CML の変動}

脾細胞の P815に対する傷害活性は, $\mathrm{E} / \mathrm{T}=30$ ： 1 では, 抗 $\mathrm{V} \beta \mathrm{mAb}$ 投与後 3 日目に対照群が 81.9\%であったのに対し $17.2 \%$ まで低下した。 そ の後, 7 日目から 28 日目の間に $7.4 \%, 6.9 \%, 1.3 \%$ と抑制が光進した（対照は86.2\%，78.4\%， $77.7 \%)$ 。しかし, 42 日目には, MLR 同様 CML も 対照群の值にまで急激に回復し $(74.2 \%)$, 以後, 正常の細胞傷害活性を持続した。なお，同系骨髄 腫細胞 EL-4（H-2 $2^{\mathrm{b}}$ に対しては B6 細胞は傷害活 性を示さなかった（Fig.4）。

\section{考 察}

T細胞リセプターに対するモノクローナル抗体 $(\mathrm{mAb})$ は, 移植領域ばかりでなく実験的自己免疫 疾患の治療や疾病の予防にも種々利用されてい る.例えば, マウスの experimental allergic encephalomyelitis (EAE) は, $\alpha \beta \mathrm{TCR}+$ 細胞の中で も V $\beta 8$ を使用する細胞群が疾病に関与すると言 われ，V $\beta 8$ に特異的な $\mathrm{mAb}$ の投与で予防できる ことが報告されている17,18)。 また，マウスの collagen induced arthritis も特定の $\mathrm{V} \beta \mathrm{TCR}+$ 細胞 が関与すると言われ，H57を投与しその細胞の働 きを抑制すると，発症が予防されることが最近明 らかになっだ、19.

このように疾患の原因が一つに絞られる場合 は, $\mathrm{mAb}$ の使用で比較的十分な効果を得やすい が, 様々な細胞が多様な抗原を諗識し拒絶を惹起 すると考えられる臓器移植では, 単一の $\mathrm{mAb}$ 拒絶反応を抑制し臓器の長期生着を期待するのは 困難である.さらに，抗体投与によって引き起こ される lympholysisは，免疫系のネットワークに 

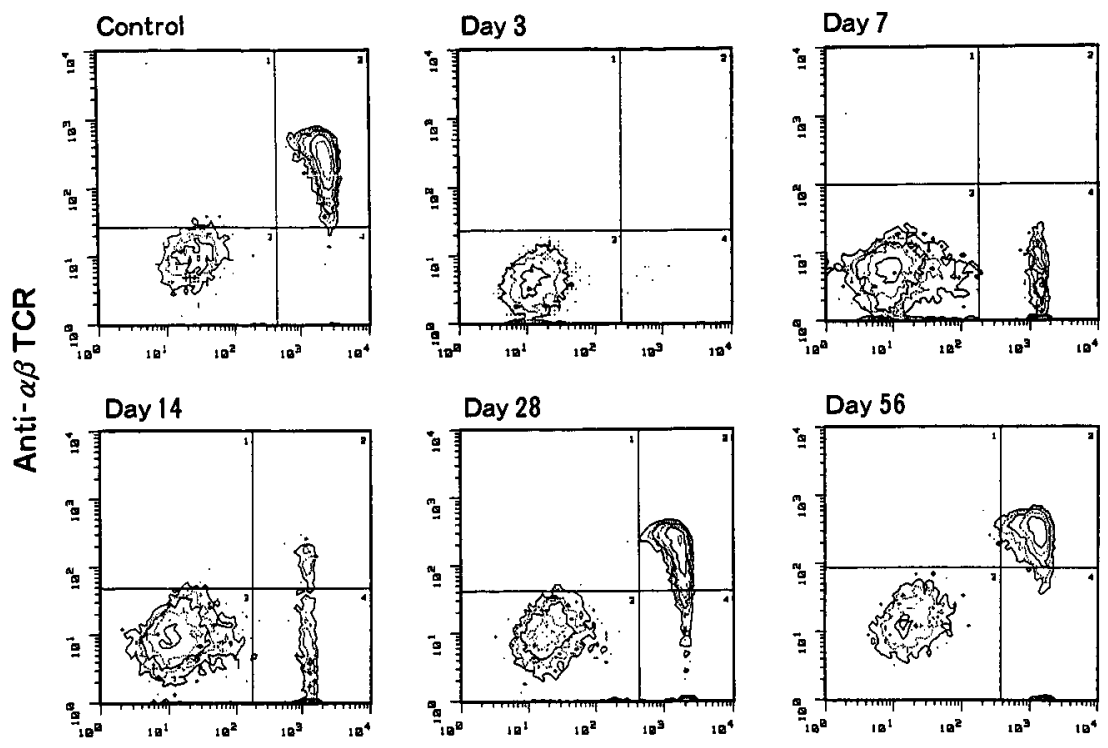

\section{Day 28}

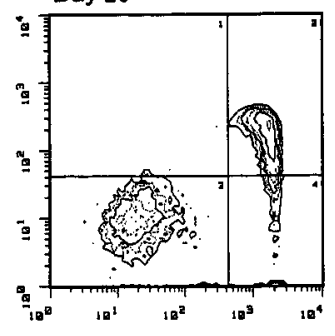

Anti-Thy-1.2

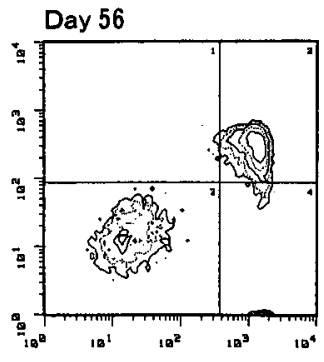

Fig. 2 Discrimination of Thy $-1.2^{+} \mathrm{TCR} \alpha \beta^{+}$cells in lymph node after treatment with anti-V $\beta$ mAb. Two-color FCM was done at weekly intervals on lymph node cells from B 6 mice injected with single dose $(250 \mu \mathrm{g})$ of anti-V $\beta$ mAb. Cells were stained with the same method shown in Fig. 1. A total of 10,000 cells were analyzed in each sample.

破綻を引き起こす結果種々の副作用が生じ，その 対策も必要になってくる ${ }^{20)}$. 例えば, OKT3 mAb (マウスモデルでは145-2C11) は, CD3の $\varepsilon$ 鎖に結 合し移植片の生着にその効果を発揮するが, 発熱, 食思不振等の副作用に加えて，長期の生着が得ら れない等の欠点を持っている21. 今回使用した抗 $\mathrm{V} \beta \mathrm{mAb}$ は, 投与の際の注意深い観察にも拘ら ず，マウスに食思不振など通常の行動を抑制する と思われる副作用は全く認められなかった。

抗 V $\beta$ mAb はすべての TCR の $\beta$ 鎖に結合す る. 抗 $\mathrm{V} \beta \mathrm{mAb} 250 \mu \mathrm{g}$ の一回投与によって, 未 梢血, リンパ節, 脾臓の Thy-1.2+ $\alpha \beta$ TCR ${ }^{+}$細胞 は3日目から 7 日目まで検出困難な状態にまで減 少した(Fig. 1).しかし, Thy-1.2+細胞はこの間 でも約 $26 \%$ は残存していた。一方, 抗 $\mathrm{V} \beta \mathrm{mAb}$ 投 与後の脾細胞の増殖反応は56日目で完全に回復す るものの，3日目では対照の $2.6 \% ， 7$ 日目に $19.3 \%$ (いずれも 5 日間混合培養）と著しく低下 した (Fig. 3)。細胞傷害活性も同様に完全に回復 したのは56日目であったが，3日目では $17.2 \%$ ，
7 日目では7.4\%(E/T=30：1) と低下した (Fig. 4).このように, 抗 $\mathrm{V} \beta \mathrm{mAb} 100 \mu \mathrm{g}$ または $250 \mu \mathrm{g}$ 一回投与で $\alpha \beta \mathrm{TCR}+$ 細胞は末梢血, リンパ節, 脾 臓で激隇したにも拘らず(Fig. 1), 移植片の生着 期間は対照群と有意の差が認められなかった (Table 1. group 3, group 5). その理由は明らか ではないが, 測定した組織以外, 例えば, 移植局 所の組織などに残存する $\alpha \beta \mathrm{TCR}+$ 細胞に起因す るか, 或いは, $\alpha \beta \mathrm{TCR}^{+}$細胞以外の細胞が拒絶に 関与する可能性が考えられる。 そこで， $\alpha \beta \mathrm{TCR}^{+}$ 細胞をより完全に除去する目的で, $100 \mu \mathrm{g}$ または $250 \mu \mathrm{g}$ 抗 $\mathrm{V} \beta \mathrm{mAb}$ を術後 $3 ， 7 ， 10$ 日に投与する

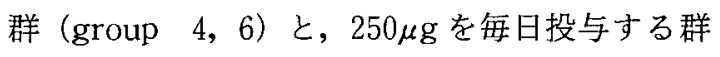
(group 7) を設けて検討した.いずれも生着期間

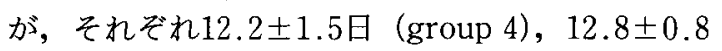

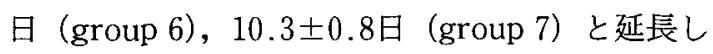
た $(\mathrm{p}<0.001)$ (Table 1). 手術時に存在している $\alpha \beta \mathrm{TCR}+$ 細胞をも除く目的で皮膚移植 1 週間前 に抗 $\mathrm{V} \beta \mathrm{mAb} 100 \mu \mathrm{g}$ を投与し, 更に移植直後加 ら 3，7，10日目に抗体を追加投与してみたが 

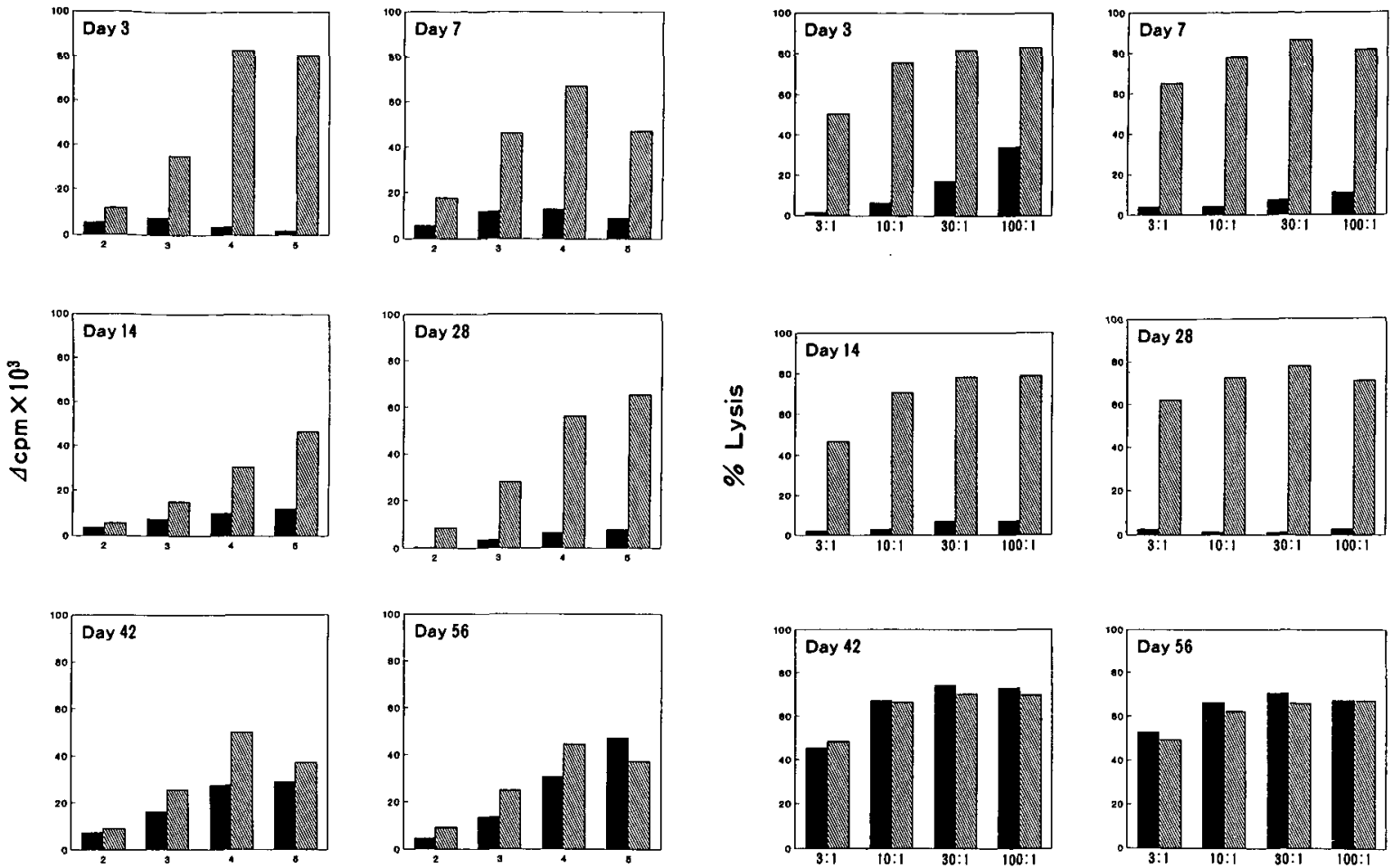

Days cultured

Fig. 3 MLR response of anti-V $\beta$ mAb-treated B 6 splenocytes. Each MLR assay was done at weekly intervals. Responder splenocytes from $\mathrm{B} 6$ mice injected with single dose $(250 \mu \mathrm{g})$ of anti-V $\beta \mathrm{mAb}(\boldsymbol{\square})$ and untreated B 6 mice $(\mathbb{S})$ were cultured with stimulator splenocytes from irradiated B 6 (syngeneic MLR) or DBA (allogeneic MLR) mice for 2 to 5 days. Results are shown as $\Delta \mathrm{cpm}$, calculated as allogeneic MLR minus syngeneic MLR.

( $\mathrm{n}=2$, data 未発表)，移植片は11日目で拒絶され 更に延長することはなかった。

抗 $\mathrm{V} \beta \mathrm{mAb}$ の頻回投与により,より十分な $\alpha \beta$ $\mathrm{TCR}^{+}$細胞を除去することで移植片の生着が延長 する. 従って，一回投与により移植片の生着の延 長が認められなかった機序の一つは，残存する $\alpha \beta \mathrm{TCR}^{+}$細胞によるものと思われる。しかし，抗 体を頻回投与したにも拘らず，4 日以上の延長が 認められなかった．抗 $\mathrm{V} \beta \mathrm{mAb}$ を一回投与した マウスの脾臟細胞では，投与 3 週間後でも MLR
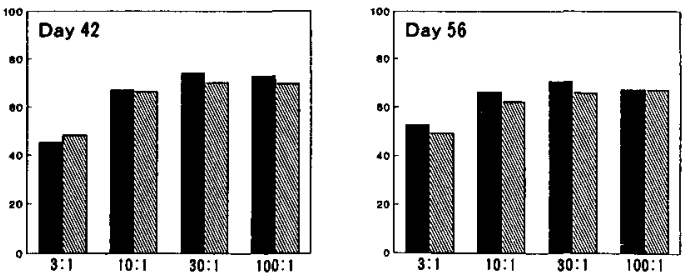

E/T Ratio

Fig. 4 CML response of anti- $\mathrm{V} \beta$ mAb-treated B 6 splenocytes. Each CML assay was done at weekly intervals. Effector splenocytes from B 6 mice injected with single dose $(250 \mu \mathrm{g})$ of anti-V $\beta \mathrm{mAb}(\mathbf{\square})$ and untreated $\mathrm{B} 6$ mice $(\mathbb{\mathbb { S }})$ were tested for their cytolytic reactivity against ${ }^{51} \mathrm{Cr}$-labeled P $815\left(\mathrm{H}-2^{\mathrm{d}}\right)$ and EL-4 $\left(\mathrm{H}-2^{\mathrm{b}}\right)$ targets following 5 days of culture with irradiated DBA splenocytes. None of the mAbtreated splenocytes had significant cytolytic reactivity against syngeneic EL-4 targets.

(Fig. 3) や CML (Fig. 4) は著しく抑制された ままである。この事実からすれば，術後12日以上 の生着を期待しても不思議ではない.しかし, 抗 体の一回投与によって $\alpha \beta \mathrm{TCR}+$ 細胞は測定限界 以下になるが, Thy $-1.2^{+} \alpha \beta \quad \mathrm{TCR}^{+}$細胞以外の Thy-1.2+細胞群は完全に除去されることなく, 26\%程度残存する (Fig. 1). Thy-1抗原陽性細胞 は $\alpha \beta \quad \mathrm{TCR}+$ 細胞のみでなく, $\gamma \delta \mathrm{TCR}^{+}$細胞や $\mathrm{NK}$ 細胞, 或いは, $\mathrm{T}$ 細胞以外の細胞にも認めら 
れる ${ }^{22)}$. 移植免疫に関与する免疫系の細胞として， マクロファージ， NK 細胞， $\alpha \beta \mathrm{TCR}+$ 細胞， $\gamma \delta$ $\mathrm{TCR}^{+}$細胞等があるが，抗原特異的に反応する主 たる細胞は $\alpha \beta \mathrm{TCR}^{+}$細胞と $\gamma \delta \mathrm{TCR}^{+}$細胞であ る. 従って，抗 $\mathrm{V} \beta \mathrm{mAb}$ の投与により $\alpha \beta \mathrm{TCR}^{+}$ 細胞の影響をほとんど除外したと思われるマウス でみられる移植片の特異的拒絶は, $\gamma \delta \mathrm{TCR}+$ 細胞 による可能性が考えられる。 $\gamma \delta \mathrm{TCR}+$ 細胞は分布 する臟器により使用する V 領域が異なり, マウス では皮膚や消化管粘膜に多く存在し，ほとんどが Thy $-1^{+} \mathrm{CD}^{+} \mathrm{CD} 4{ }^{-} \mathrm{CD} 8^{-}$である ${ }^{23,24)}$. 最近, $\gamma \delta$ $\mathrm{TCR}^{+}$細胞がクラス I, クラス II MHC 拘束性に アロ抗原を認識し, 細胞増殖や細胞傷害活性を示 すことが明らかにされた ${ }^{25,26)}$.マウスの皮膚には Thy-1が陽性で， $\gamma \delta$ TCR 陽性の樹枝状表皮細胞 (Thy-1+DEC) や，抗原提示細胞 (APC) として 㗢くランゲルハンス細胞が存在し, 拒絶反応に関 与することが知られている ${ }^{27 \sim 29)}$ ：従って，抗 V $\beta$ $\mathrm{mAb}$ の頻回投与によって, 4 日以上移植片の生着 延長が認められなかった機序の一つは, $\gamma \delta \mathrm{TCR}^{+}$ 細胞による可能性も考えられる。すなわち，抗 $\alpha \beta$ $\mathrm{TCR}$ モノクローナル抗体（抗 V $\beta \mathrm{mAb}$ ) の投与 によって $\alpha \beta \mathrm{TCR}+$ 紐胞の活性を抑制することは できるが，単独投与で長期間にわたる拒絶反応抑 制を誘導できなかった原因の一つは，移植片の拒 絶反応には， $\alpha \beta \mathrm{TCR}^{+}$細胞以外に, $\gamma \delta \mathrm{TCR}^{+}$細 胞や他の末知の細胞が関与することによると思わ れれる。

\section{結 論}

抗 $\alpha \beta$ TCR モノクローナル抗体 (抗 V $\beta$ mAb) を用いて，マウスの同種皮䖉移植における拒絶反 応抑制効果，および $\alpha \beta \mathrm{TCR}^{+} \mathrm{T}$ 細胞数の割合の 変化, 機能の抑制, 回復過程に付いて検討を行い 下記の結果を得た。

1) 抗 V $\beta$ mAb $100 \mu \mathrm{g}$ または $250 \mu \mathrm{g}$ を移植当 日と $3,7,10$ 日後に投与すると, 移植皮獻片は 平均12日間生着した。これは対照に比べ，4日間 の生着延長である。

2) 抗 $\mathrm{V} \beta \quad \mathrm{mAb} 250 \mu \mathrm{g}$ 一回投与により $\alpha \beta$ $\mathrm{TCR}+$ 細胞は, 末梢血, リンパ節, 脾で投与 3 日後
から約 1 週間検出困難なレベルにまで減少, 以後 漸増した。 8 週間後, 未梢血では細胞数の割合が 完全に回復したが, リンパ節, 脾では約 $60 \%$ の回 復であった. 一方抗 $\mathrm{V} \beta \mathrm{mAb}$ 投与マウスの脾細. 胞は, 投与 3 日後から 28 日後まで, MLR や CML の有意な抑制が続くが，8週間後には完全に回復 した。

3） $\alpha \beta$ TCR 特異的抗 $\mathrm{V} \beta \mathrm{mAb}$ の投与により, $\alpha \beta \mathrm{TCR}+$ 細胞が末梢 (末梢血, リンパ節，脾臓) より消失するにも拘らず，移植片の生着に 4 日以 上の延長が認められないところから, マウスの同 種皮膚移植片の拒絶には, $\alpha \beta \mathrm{TCR}+$ 細胞以外の細 胞, 特に抗原特異的 $\gamma \delta \mathrm{TCR}+$ 細胞の役割を考慮す る必要があるであろう。

稿を終えるにあたり，ご指導ここ校閲を賜った現シンシ ナチ大学外科 associate professor Douglas W. Hanto M. D. Ph. D. 及び日本医科大学外科学第 2 教室庄司 佑教授, 微生物学免疫学教室横窒公三教授に深謝いたします。また， ご助言, ご協力いただいた外科学第 2 教室渋谷哲男助教授 に感謝いたします。

\section{文 献}

1) Bjorkman, P.J., Saper, M.A., Samraoui, B., Bennett, W.S., Strominger, J.L., and Wiley, D.C. : Structure of the human class I histocompatibility antigen, HLA-A2. Nature, 329, 506 512, 1987.

2) Babbitt, B.P., Allen, P.M., Matsueda, G., Haber, E., and Unanue, E.R.: Binding of immunogenic peptides to Ia histocompatiblity molecules. Nature, 317, 359 361, 1985.

3) Davis, M.M., and Bjorkman, P.J.: T.cell antigen receptor genes and T-cell recognition. Nature, 334, 395 402, 1988.

4) Kahan, B.D.: Cyclosporine. N. Engl. J. Med., 321, 1725 1738, 1989 .

5) Schreiber, S.L., and Crabtree, G.R.: The mechanism of action of cyclosporin A and FK506. Immunol. Today, 13, 136 142, 1992.

6) Leo, O., Foo, M., Sachs, D.H., Samelson, L.E., and Bluestone, J.A.: Identification of a monoclonal antibody specific for a murine T3 polypeptide.Proc. Natl. Acad. Sci. USA, 84, 1374 1378, 1987.

7) Kirkman, R.L., Barrett, L.V., Gaueton, G.N., Kelley, V.E., Koltun, W.A., Schoen, F.J., Ythier, A., and Strom, T.B.: The effect of anti-interleukin-2 receptor monoclonal antibody on allograft rejection. Transplantation, 40, 719 722, 1985. 
8) Isobe, M., Yagita, H., Okumura, K., and Ihara, A. : Specific acceptance of cardiac allograft after treatment with antibodies to ICAM-1 and LFA-1. Science, 255, 1125 1127, 1992.

9) Saito, H., Kranz, D.M., Takagaki, Y.; Hayday, A. C., Eisen, H.N., and Tonegawa, S.: Complete primary structure of a heterodimeric T-cell receptor deduced from cDNA sequences. Nature, 309, 757 762, 1984.

10) Yanagi, Y., Yoshikai, Y., Leggett, K., Clark, S.P., Aleksander, I., and Mak, T.W.: A human T cellspecific cDNA clone encodes a protein having extensive homology to immunoglobulin chains. Nature, 308, 145 149, 1984.

11) Dembic, Z., Haas, W., Weiss, S., McCubrey, J., Kiefer, H., Boehmer, $H$. and Steinmetz, M.: Transfer of specificity by murine $\alpha$ and $\beta$ T-cell receptor genes. Nature, 320, 232 238, 1986.

12) Clevers, H., Alarcon, B., Wileman, T., and Terhorst, C.: The $\mathrm{T}$ cell receptor/CD3 complex; A dynamic protein ensemble. Ann. Rev. Immunol., 6, $629 \sim 662,1988$.

13) Chien, Y., Iwashima, M., Kaplan, K.B., Elliott, J.F., and Davis, M.M.: A new T-cell receptor gene located within the alpha locus and expressed early in T-cell differentiation. Nature, 327, 677 682 , 1987.

14) Brenner, M.B., McLean, J., Scheft, H., Riberdy, J., Ang, S., Seidman,J.G., Devlin, P., and Krangel, M. S.: Two forms of the T-cell receptor $\gamma$ protein found on peripheral blood cytotoxic $T$ lymphocytes. Nature, 325, 689 694, 1987.

15) Kubo, R., Born, W., Kappler, J.W., Marrack, P., and Pigeon, M.: Characterization of a monoclonal antibody which detects all murine $\alpha \beta$ T cell receptors. J. Immunol., 142, 2736 2742, 1989.

16) Billingham, R.E., and Medawar, P.B.: The technique of free skin grafting in mammals. J. Exp. Biol., 28, 385 402, 1951.

17) Acha-Orbea, H., Mitchell, D.J., Timmermann, L., Wraith, D.C., Tausch, G.S., Waldor, M.K., Zamvil, S.S., McDevitt, H.O., and Steinman, L.: Limited heterogeneity of $\mathrm{T}$ cell receptors from lymphocytes mediating autoimmune encephalomyelitis allows specific immune intervention. Cell, 54, 263 273, 1988.

18) Urban, J.L., Kumar, V., Kono, D.H., Gomez, C., Horvath, S.J., Clayton, J., Ando, D.G., Sercarz, E.E., and Hood, L. : Restricted use of T cell receptor V genes in murine autoimmune encephalomyelitis raises possibilities for antibody therapoy. Cell, 54, 577 592, 1988.

19) Moder, K.G., Luthra, H.S., Kubo, R., Griffiths, M., and David, C.S.: Prevention of collagen induced arthritis in mice by treatment with an antibody directed against the $\mathrm{T}$ cell receptor $\alpha \beta$ framework. Autoimmunity, 11, 219 224, 1992.

20) Reinherz, E.L., Hussey, R.E., and Schlossman, S.F. : A monoclonal antibody blocking human $T$ cell function. Eur. J. Immunol., 10, 758 762, 1980.

21) Hirsch, R., Eckhaus, M., Auchincloss, H., Jr., Sachs, D.H., and Bluestone, J.A.: Effects of in vivo administration of anti-T3 monoclonal antibody on $\mathrm{T}$ cell function in mice. J. Immunol., 140, 3766 3722, 1988 .

22) Kimball, J.W.: The tissues and cells of the immune system. In: Introduction to immunology. Macmillan Publishing Company, New York, 1986, $147 \sim 149$.

23) Tonegawa, S., Berns, A., Bonneville, M., Farr, A.G., Ishida, I., Ito, K., Itohara, S., Janeway, C.A., Kanagawa, O., Kubo, R., Lafaille, J.J., Murphy, D.B., Nakanishi, N., Takagaki, Y., and Veebeek, S.: Diversity, development, ligands, and probable functions of $\gamma \delta$ T cells. Adv. Exp. Med. Biol., 292, 53〜61, 1991.

24) Bonneville, M., Janeway, C.A.; Ito, K., Haser, W., Ishida, I., Nakanishi, N., and Tonegawa, S. : Intestinal intraepithelial lymphocytes are a distinct set of $\gamma \delta$ T cells. Nature, 336, 479 481, 1988.

25) Matis, L.A., Cron,R., and Bluestone, J.A.: Major histocompatibility complex-linked specificity of $\gamma \delta$ receptor-bearing $\mathrm{T}$ lymphocytes. Nature, 330, 262 264, 1987.

26) Matis, L.A., Fry, A,M., Cron, R.Q., Cotterman, M. M., Dick, R.F., and Bluestone, J.A. : Structure and specificity of a class II MHC alloreactive $\gamma \delta \mathrm{T}$ cell receptor heterodimer. Science, 245, 746 749, 1989.

27) Rivas, A., Koide, J., Cleary, M.L., and Engleman, E. G.: Evidence for involvement of the $\gamma \delta \mathrm{T}$ cell antigen receptor in cytotoxicity mediated by human alloantigen-specific $\mathrm{T}$ cell clones. J. Immunol., 142, 1840 1846, 1989.

28) Koning, F., Stingl, G., Yokoyama, W.M., Yamada, H., Maloy, W.L., Tschachler, E., Shevach, E.M., and Colign, J.E. : Identification of a T3-associated $\gamma \delta$ $\mathrm{T}$ cell receptor on Thy-1+ $1^{+}$dendritic epidermal cell lines. Science, 236, 834 837, 1987.

29) Streilein, J.W., Toewes, G.T., Gilliam, J.N., and Bergstresser,P.R.: Tolerance or hypersensitivity to 2,4-dinitro-1-fluorobenzene: The role of Langerhans cell density within epidermis. J. Invest. Dermatol., 74, 319 322, 1980.

（受付：1994年2月14日） 